\title{
ELEMENTAL BIOAVAILIBILITY IN NUTRIENT SOLUTIONS IN RELATION TO PRECIPITATION REACTIONS
}

De Rijck G. and Schrevens E.

Faculty of Agricultural and Applied Biological Sciences

Department of Applied Plant Sciences K.U.Leuven

Willem de Croylaan 42, B-3001 Heverlee (Belgium)

\section{ABSTRACT}

In hydroponic plant nutritional research, nutrient solutions can be considered as aqueous solutions of inorganic ions. In this aqueous solution the ions are submitted to the laws of aquatic inorganic chemistry. This means that the ions are involved in the dynamic equilibria between complexation, dissociation and precipitation reactions. These chemical reactions seriously impact elemental speciation and bioavailability. As a result, plant roots experience a different nutritional composition.

Ions withdrawn from the nutrient solution due to precipitation reactions, change the nutritional composition and are not available for uptake by plant roots. Like complexes, precipitates can buffer a nutrient solution, exchanging nutrients as these decrease by plant uptake.

This research looks into the precipitation reactions that occur in hydroponic nutrient solutions. In the concentration range of nutrient solutions no precipitates are formed involving potassium, nitrate, ammonium or sulphate, while $\mathrm{Ca}^{2+}$ and $\mathrm{Mg}^{2+}$ form mainly at a higher $\mathrm{pH}$ precipitates with $\mathrm{HPO}_{4}{ }^{2-}$. Preparing nutrient solutions with tap-water, $\mathrm{CaCO}_{3}$ is likely to precipitate.

A good knowledge of the chemical reactions occurring in nutrient solutions is the first prerequisite in hydroponic plant nutritional research. 


\section{INTRODUCTION}

The laws of aquatic inorganic chemistry distribute the ions in nutrient solutions among their various chemical and physical forms like: free ions, soluble complexes, chelates, ionpairs, solid and gaseous phases and different oxidation states, called "elemental speciation". Each of these chemical and physical forms possesses a different reactivity, mobility and different physicochemical properties, changing bioavailability.

The inorganic ions present in nutrient solutions can form precipitates. Precipitated elements are not available for uptake by plants. In this way, precipitation reactions like dissociation and complexation reactions change the mineral composition of nutrient solutions (De Rijck et al., 1997a, 1997b).

The precipitation reactions involving the six essential macronutrients $\left(\mathrm{K}^{+}, \mathrm{Ca}^{2+}, \mathrm{Mg}^{2+}\right.$, $\mathrm{NO}_{3}{ }^{-}, \mathrm{H}_{2} \mathrm{PO}_{4}{ }^{-}$and $\mathrm{SO}_{4}{ }^{2-}$ ) are elaborated. Since hydroponic nutrient solutions sometimes contain ammonium and bicarbonate in a millimolar range, also the precipitation reactions involving these two ions are considered.

\section{MATERIAL AND METHODS}

\section{$\underline{\text { Calculations }}$}

The calculations are carried out with the conditional equilibrium constants of the computer speciation program Geochem PC version 2.0 (Parker et al., 1995), adjusted at an ionic strength of $30 \mathrm{mmol} / \mathrm{l}$, the concentration range of nutrient solutions. This means that the calculations are correct if beside the considered chemical entity other ions are present, inert for the considered chemical reactions, at a concentration so that the total ionic strength equals $30 \mathrm{mmol} / \mathrm{l}$.

The effect of temperature, atmospheric pressure and atmospheric composition is not taken into account. All the calculations are made for closed systems (no $\mathrm{CO}_{2}$ exchange with the atmosphere) at a temperature of $25^{\circ} \mathrm{C}$, an atmospheric pressure of $0.1 \mathrm{Mpa}$ and a total ionic strength of $30 \mathrm{mmol} / \mathrm{l}$.

\section{Precipitation reactions}


In a precipitation reaction certain cations combine with certain anions to form an insoluble solid called a precipitate (Skoog et al., 1976):

$\mathrm{M}_{\mathrm{k}} \mathrm{L}_{\mathrm{n}(\mathrm{S})} \leftrightarrow \mathrm{k} \mathrm{M}^{\mathrm{m}+}{ }_{(\mathrm{aq})}+\mathrm{n} \mathrm{L}^{1-}{ }_{(\mathrm{aq})}$

with: 1 : valence of the anion

$\mathrm{m}$ : valence of the cation

The solubility product constant " $\mathrm{K}_{\mathrm{sp}}$ " is a measure for the equilibrium between a precipitate and its ions in a saturated solution (Cotton et al., 1980):

$\mathrm{K}_{\mathrm{sp}}=\left[\mathrm{M}^{\mathrm{m}+}\right]^{\mathrm{k}}\left[\mathrm{L}^{1-}\right]^{\mathrm{n}}$

Considering equation (1), it is clear that for each mole of $\mathrm{M}_{k} \mathrm{~L}_{n}$ that dissolves $k$ moles of $\mathrm{M}^{\mathrm{m}+}$ and $\mathrm{n}$ moles of $\mathrm{L}^{1-}$ appear in the solution. If $\mathrm{S}$ is the molar solubility of $\mathrm{M}_{\mathrm{k}} \mathrm{L}_{\mathrm{n}}$, then

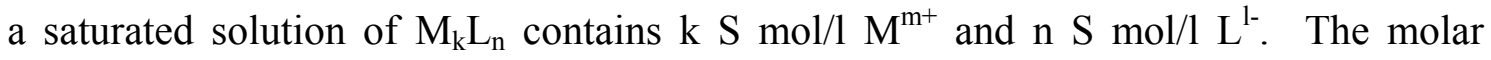
solubility ( $S$ ) of $M_{k} L_{n}$ is calculated as follows:

$\mathrm{K}_{\mathrm{sp}}=\left[\mathrm{M}^{\mathrm{m}+}\right]^{\mathrm{k}}\left[\mathrm{L}^{\mathrm{l}-}\right]^{\mathrm{n}}=(\mathrm{k} \mathrm{S})^{\mathrm{k}}(\mathrm{n} \mathrm{S})^{\mathrm{n}}$

The molar solubility (S) can be expressed with the following equation:

$\mathrm{S}=(\mathrm{n}+\mathrm{k}) \sqrt{\frac{\mathrm{K}_{\mathrm{sp}}}{\mathrm{k}^{\mathrm{k}} \mathrm{n}^{\mathrm{n}}}}$

Precipitation reactions are influenced by phenomenons like $\mathrm{pH}$, common ion effect (precipitation effect), salt effect (activity effect) and ion pair formation (complexation). A precipitate is $\mathrm{pH}$ dependent if its cation or anion takes part in an acid - base equilibrium.

The common ion effect is also called the "primary salt effect". If a certain concentration of XL is added to a saturated $\mathrm{M}_{1} \mathrm{~L}_{m}$ solution, a certain amount of $\mathrm{M}_{1} \mathrm{~L}_{m}$ will precipitate, resulting in a lower $\mathrm{M}^{\mathrm{m}+}{ }_{(\mathrm{aq})}$, and a higher $\mathrm{L}^{1-}{ }_{(\mathrm{aq})}$ concentration.

The presence of other ions also impacts solubility. This effect is opposite to the common ion effect and was called the "secondary salt effect". If other ions are dissolved, the total ionic concentration of the solution increases and interionic attractions become important. Activities become smaller than the stoichiometric or measured concentrations. Higher concentrations of the ions are necessary before 
equilibrium is established (Petrucci et al., '93). This means that the solubility increases in solutions of higher concentrations.

Ion pair formation or complexation increases the solubility. In a saturated solution of $\mathrm{M}_{1} \mathrm{~L}_{\mathrm{m}}$ there exist combinations of one $\mathrm{M}^{\mathrm{m}+}{ }_{\text {(aq) }}$ ion and one $\mathrm{L}^{1-}{ }_{(\mathrm{aq})}$ ion present in solution as the ion pair $\mathrm{ML}^{\mathrm{m}-1}$ (aq). The amount of ions taking part in the formation of ion pairs reduces the concentration of the dissociated ions. Higher amounts of the solute must be dissolved to maintain the required ion concentration to satisfy the solubility product constant.

For slightly soluble salts $\left(\mathrm{CaSO}_{4} 2 \mathrm{H}_{2} \mathrm{O}, \mathrm{CaHPO}_{4}, \ldots\right)$ the solubility product constants are used in a correct way. If moderately or highly soluble salts $\left(\mathrm{MgNO}_{3}, \mathrm{KNO}_{3}, \ldots\right)$ are used, the $\mathrm{K}_{\mathrm{sp}}$ value must be based on ion activities rather than on concentrations.

In an aqueous solution of the six essential macronutrients $\mathrm{K}^{+}, \mathrm{Ca}^{2+}, \mathrm{Mg}^{2+}, \mathrm{NO}_{3}{ }^{-}, \mathrm{H}_{2} \mathrm{PO}_{4}^{-}$ and $\mathrm{SO}_{4}{ }^{2-}$ the following precipitation reactions have to be taken into account:
$\mathrm{Ca}_{3}\left(\mathrm{PO}_{4}\right)_{2(\mathrm{~s})} \leftrightarrow 3 \mathrm{Ca}^{2+}+2 \mathrm{PO}_{4}^{3-}$
$\mathrm{K}_{\mathrm{sp}}=10^{-26.8}$
$\mathrm{CaHPO}_{4(\mathrm{~s})} \leftrightarrow \mathrm{Ca}^{2+}+\mathrm{HPO}_{4}{ }^{2-}$
$\mathrm{K}_{\mathrm{sp}}=10^{-6.0}$
$\mathrm{Ca}_{4} \mathrm{H}\left(\mathrm{PO}_{4}\right)_{3(\mathrm{~s})} \leftrightarrow 4 \mathrm{Ca}^{2+}+\mathrm{H}^{+}+\mathrm{PO}_{4}{ }^{3-}$
$\mathrm{K}_{\mathrm{sp}}=10^{-43.9}$
$\mathrm{CaSO}_{4(\mathrm{~s})} \leftrightarrow \mathrm{Ca}^{2+}+\mathrm{SO}_{4}^{2-}$
$\mathrm{K}_{\mathrm{sp}}=10^{-4.0}$
$\mathrm{Ca}(\mathrm{OH})_{2(\mathrm{~s})} \leftrightarrow \mathrm{Ca}^{2+}+2 \mathrm{OH}^{-}$
$\mathrm{K}_{\mathrm{sp}}=10^{-3.16}$
$\mathrm{Mg}_{3}\left(\mathrm{PO}_{4}\right)_{2(\mathrm{~s})} \leftrightarrow 3 \mathrm{Mg}^{2+}+2 \mathrm{PO}_{4}^{3-}$
$\mathrm{K}_{\mathrm{sp}}=10^{-22.9}$
$\mathrm{MgHPO}_{4(\mathrm{~s})} \leftrightarrow \mathrm{Mg}^{2+}+\mathrm{HPO}_{4}{ }^{2-}$
$\mathrm{K}_{\mathrm{sp}}=10^{-5.3}$
$\mathrm{MgSO}_{4(\mathrm{~s})} \leftrightarrow \mathrm{Mg}^{2+}+\mathrm{SO}_{4}^{2-}$
$\mathrm{K}_{\mathrm{sp}}=10^{-1.6}$
$\mathrm{Mg}(\mathrm{OH})_{2(\mathrm{~s})} \quad \leftrightarrow \quad \mathrm{Mg}^{2+}+2 \mathrm{OH}^{-}$
$\mathrm{K}_{\mathrm{sp}}=10^{-7.9}$

Tetracalciumhydrogentriphosphate,

tricalciumdiphosphate

and trimagnesiumbiphosphate are very insoluble precipitates. At the $\mathrm{pH}$ range of nutrient solutions almost no $\mathrm{PO}_{4}{ }^{3-}$ is present. Should this case arise considerable amounts of the respective cations and anions would precipitate.

In nutrient solutions containing ammonia and inorganic carbonate also the following precipitation reactions have to be considered:
$\mathrm{CaCO}_{3(\mathrm{~s})} \leftrightarrow \mathrm{Ca}^{2+}+\mathrm{CO}_{3}{ }^{2-}$
$\mathrm{K}_{\mathrm{sp}}=10^{-7.8}$ 


$$
\begin{array}{ll}
\mathrm{MgCO}_{3(\mathrm{~s})} \leftrightarrow \mathrm{Mg}^{2+}+\mathrm{CO}_{3}{ }^{2-} & \mathrm{K}_{\mathrm{sp}}=10^{-6.9} \\
\mathrm{Mg}_{5}(\mathrm{OH})_{2}\left(\mathrm{CO}_{3}\right)_{4(\mathrm{~s})} \leftrightarrow 5 \mathrm{Mg}^{2+}+2 \mathrm{OH}^{-}+4 \mathrm{CO}_{3}{ }^{2-} & \mathrm{K}_{\mathrm{sp}}=10^{-9.1}
\end{array}
$$

Using tap-water, magnesium and calcium ions may precipitate, changing the mineral composition of the nutrient solution. Potassium and ammonium ions are not involved in precipitation reaction.

\section{RESULTS AND DISCUSSION}

\section{$\underline{\mathrm{Ca}_{3}\left(\mathrm{PO}_{4}\right)_{2} \text { and } \mathrm{Mg}_{3}\left(\mathrm{PO}_{4}\right)_{2}}$}

Figure 1 represents the solubility of $\mathrm{Ca}_{3}\left(\mathrm{PO}_{4}\right)_{2}$ and $\mathrm{Mg}_{3}\left(\mathrm{PO}_{4}\right)_{2}$ as a function of the $\mathrm{PO}_{4}{ }^{3-}$ concentration and the concentration of the respective cation. For each $\mathrm{PO}_{4}{ }^{3-}$ concentration the maximum allowed $\mathrm{Ca}^{2^{+}}$or $\mathrm{Mg}^{2+}$ concentration can be calculated. Both $\mathrm{Ca}_{3}\left(\mathrm{PO}_{4}\right)_{2}$ and $\mathrm{Mg}_{3}\left(\mathrm{PO}_{4}\right)_{2}$ are very insoluble. Only very small concentrations of both cation and anion are present in a saturated solution. For a total phosphate concentration of $2.25 \mathrm{mmol} / \mathrm{l}$ there is only $310^{-12} \mathrm{mmol} / 1$ of $\mathrm{PO}_{4}{ }^{3-}$ present at $\mathrm{pH} 5$. Due to this low $\mathrm{PO}_{4}{ }^{3-}$ concentration in a general hydroponic nutrient solution, no $\mathrm{Ca}_{3}\left(\mathrm{PO}_{4}\right)_{2}$ nor $\mathrm{Mg}_{3}\left(\mathrm{PO}_{4}\right)_{2}$ precipitates.

$\mathrm{CaHPO}_{4}$ and $\mathrm{MgHPO}_{4}$

Hydrogenphosphate forms precipitates with both calcium and magnesium. In a nutrient solution with a total phosphate concentration of $2.25 \mathrm{mmol} / \mathrm{l}$, there is $0.026 \mathrm{mmol} / 1$ $\mathrm{HPO}_{4}{ }^{2-}$ present at $\mathrm{pH}$ 5. At this $\mathrm{HPO}_{4}{ }^{2-}$ concentration and taking only the respective precipitation reactions into account, the maximum allowed calcium and magnesium concentrations is 39 and $197 \mathrm{mmol} / \mathrm{l}$ respectively (Figure 2). So, at this $\mathrm{pH}$ nor $\mathrm{CaHPO}_{4}$ nor $\mathrm{MgHPO}_{4}$ precipitates in the concentration range of nutrient solutions. However, as the $\mathrm{pH}$ of the nutrient solution increases, $\mathrm{CaHPO}_{4}$ and $\mathrm{MgHPO}_{4}$ may precipitate. 
$\underline{\mathrm{CaSO}_{4} \text { and } \mathrm{Ca}(\mathrm{OH})_{2}}$

Considering only precipitation reactions, no $\mathrm{CaSO}_{4}$ precipitates at the concentration range of calcium and sulphate in nutrient solutions (Figure 3).

Due to the high solubility product constant $\left(\mathrm{K}_{\mathrm{sp}}=10^{-5.16}\right)$ no $\mathrm{Ca}(\mathrm{OH})_{2}$ precipitates in the $\mathrm{pH}$ range of nutrient solutions (Figure 4). At a $\mathrm{Ca}^{2+}$ concentration of $2.25 \mathrm{mmol} / \mathrm{l}, 55$ $\mathrm{mmol} / 1 \mathrm{OH}^{-}$or a $\mathrm{pH}$ of 12.7 is necessary to precipitate $\mathrm{Ca}(\mathrm{OH})_{2}$.

$\underline{\mathrm{Ca}_{4} \mathrm{H}\left(\mathrm{PO}_{4}\right)_{3}}$

The solubility of octo-calcium phosphate is $\mathrm{pH}$ dependent (Figure 5). Increasing $\mathrm{pH}$, increases the solubility of $\mathrm{Ca}_{4} \mathrm{H}\left(\mathrm{PO}_{4}\right)_{3}$. Due to the low $\mathrm{PO}_{4}{ }^{3-}$ concentration in nutrient solutions no $\mathrm{Ca}_{4} \mathrm{H}\left(\mathrm{PO}_{4}\right)_{3}$ precipitates.

$\underline{\mathrm{MgSO}_{4} \text { and } \mathrm{Mg}(\mathrm{OH})_{2}}$

At the $\mathrm{Mg}^{2+}$ and the $\mathrm{SO}_{4}{ }^{2-}$ concentrations present in nutrient solutions no $\mathrm{MgSO}_{4}$ precipitates (Figure 6). For a $\mathrm{Mg}^{2+}$ concentration of $1.5 \mathrm{mmol} / 1, \mathrm{a} \mathrm{SO}_{4}{ }^{2-}$ concentration of $15.6 \mathrm{~mol} / \mathrm{l}$ is necessary before $\mathrm{MgSO} 4$ precipitates.

In a general hydroponic nutrient solution no $\mathrm{Mg}(\mathrm{OH})_{2}$ precipitates (Figure 7). At a $\mathrm{Mg}^{2+}$ concentration of $1.5 \mathrm{mmol} / \mathrm{l}$, an $\mathrm{OH}^{-}$concentration of at least $3 \mathrm{mmol} / \mathrm{l}$ or a $\mathrm{pH}$ of 11.5 is necessary before $\mathrm{Mg}(\mathrm{OH})_{2}$ precipitates.

$\underline{\mathrm{CaCO}_{3} \text { and } \mathrm{MgCO}_{3}}$

At a $\mathrm{Ca}^{2+}$ concentration of $5 \mathrm{mmol} / 1, \mathrm{CaCO}_{3}$ precipitates if the $\mathrm{CO}_{3}{ }^{2-}$ concentration is 3 $\mu \mathrm{mol} / 1$ or higher (Figure 8). In tap-water with a total inorganic carbonate concentration of $5 \mathrm{mmol} / \mathrm{l}$ and a $\mathrm{pH}$ of $7, \mathrm{CO}_{3}{ }^{2-}$ is present at a concentration of $2 \mu \mathrm{mol} / \mathrm{l}$. To prevent precipitation in preparing a nutrient solution using tap-water, the $\mathrm{pH}$ is to be lowered first. Reducing the $\mathrm{pH}$ also reduces the $\mathrm{CO}_{3}{ }^{2-}$ concentration.

Since the solubility product constant of $\mathrm{MgCO}_{3}\left(\mathrm{~K}_{\mathrm{sp}}=10^{-6.93}\right)$ is about 10 times higher than that of $\mathrm{CaCO}_{3}\left(\mathrm{~K}_{\mathrm{sp}}=10^{-7.83}\right)$ no $\mathrm{MgCO}_{3}$ precipitates in nutrient solutions (Figure 9). 
$\mathrm{Mg}_{5}(\mathrm{OH})_{2}\left(\mathrm{CO}_{3}\right)_{4}$

The solubility of $\mathrm{Mg}_{5}(\mathrm{OH})_{2}\left(\mathrm{CO}_{3}\right)_{4}$ strongly decreases as $\mathrm{pH}$ increases (Figure 10). In nutrient solutions no $\mathrm{Mg}_{5}(\mathrm{OH})_{2}\left(\mathrm{CO}_{3}\right)_{4}$ precipitates.

\section{CONCLUSIONS}

In nutrient solutions no precipitates are formed involving potassium, nitrate, ammonium or sulphate.

At a higher $\mathrm{pH}, \mathrm{Ca}^{2+}$ and $\mathrm{Mg}^{2+}$ may form precipitates with $\mathrm{HPO}_{4}{ }^{2-}$. In the $\mathrm{pH}$ range of nutrient solutions $\mathrm{H}_{2} \mathrm{PO}_{4}{ }^{-}$is the dissociation form that is mainly present. In the concentration range of nutrient solutions no precipitates are formed with the different dissociation forms of phosphates. However, if the $\mathrm{pH}$ and/or the concentration range of nutrient solutions increases these precipitates can not be prevented.

If tap-water is used to prepare nutrient solutions $\mathrm{CaCO}_{3}$ precipitates. This can be prevented by lowering the $\mathrm{pH}$ of tap-water before adding the nutrients. Reducing the $\mathrm{pH}$ also reduces the amount of $\mathrm{CO}_{3}{ }^{2-}$ present.

Although in general no precipitates are formed at the concentration range of standard nutrient solutions, this may well be the case in the concentrated stock solutions or in the fertigated substrates. For tomato cropping on rockwool, nutrient solutions with an electric conductivity (EC) of $4 \mathrm{mS} / \mathrm{cm}$ or more are used. This increases the chance on the formation of precipitates. Furthermore, due to salt accumulation the nutrient solution in the substrates may easily reach an EC of $10 \mathrm{mS} / \mathrm{cm}$.

Precipitation reactions are not only harmful because of the fact that elements are withdrawn from the nutrient solution and the mineral composition changes. The formation of precipitates on valves and trickle irrigation systems results in blockages. These blockages result in a heterogeneous production, diminishing the quality of the produce. 


\section{REFERENCES}

Cotton, F.A. and G. Wilkinson, 1980. Advanced inorganic chemistry, a comprehensive text. 4th edition, John Wiley and Sons, Inc., New York.

De Rijck, G. and E. Schrevens, 1997a. Elemental bioavailibility in nutrient solutions in relation to dissociation reactions. Journal of Plant Nutrition (accepted)

De Rijck, G. and E. Schrevens, 1997b. Elemental bioavailibility in nutrient solutions in relation to complexation reactions. Journal of Plant Nutrition (submitted)

Hewitt, E.J., 1966. Sand and water culture methods used in the study of plant nutrition. Technical communication No 22 (revised). Commonwealth Bureau of Horticulture and Plantation Crops, East malling, Maidstone, Kent, England.

Parker, D.R., W.A. Norvell, and R.L. Chaney, 1995. GEOCHEM-PC: A chemical speciation program for IBM and compatible personal computers. In: Loeppert, R.H. et al. (ed.) Chemical equilibrium and reaction models. SSSA Spec. Publ. 42, SSSA, ASA, Madison, WI. 253-269.

Petrucci, R.H. and W.S. Harwood, 1993. General Chemistry. Principles and modern applications. In : Corey P.F., Macmilan Publishing Company, New York.

Skoog, D.A. and D.M. West, 1976. Fundamentals of analytical chemistry. Third edition. In: Holt, Rinehart and Winston, New York. 







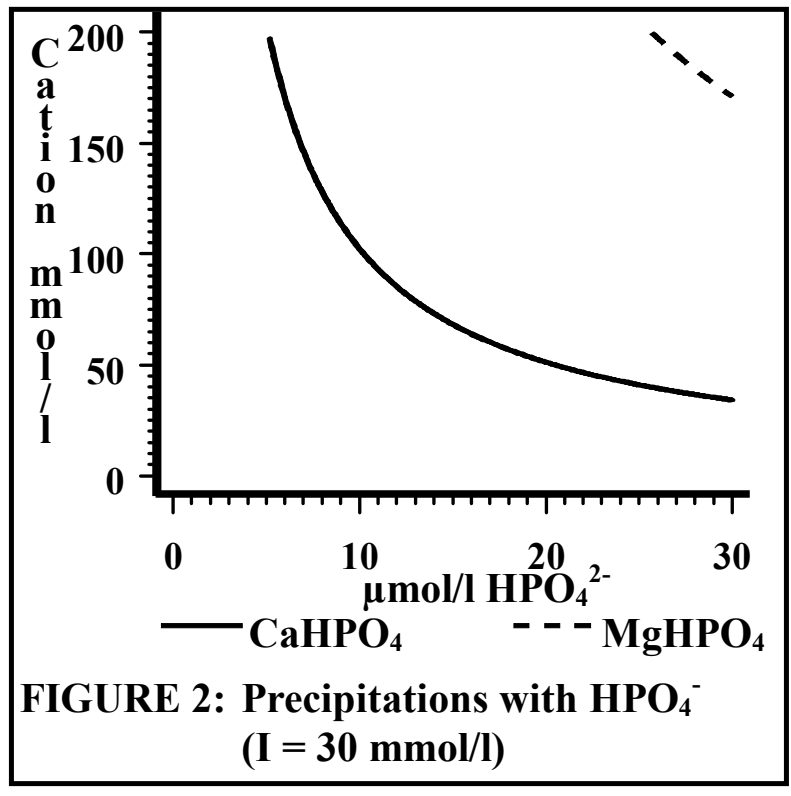




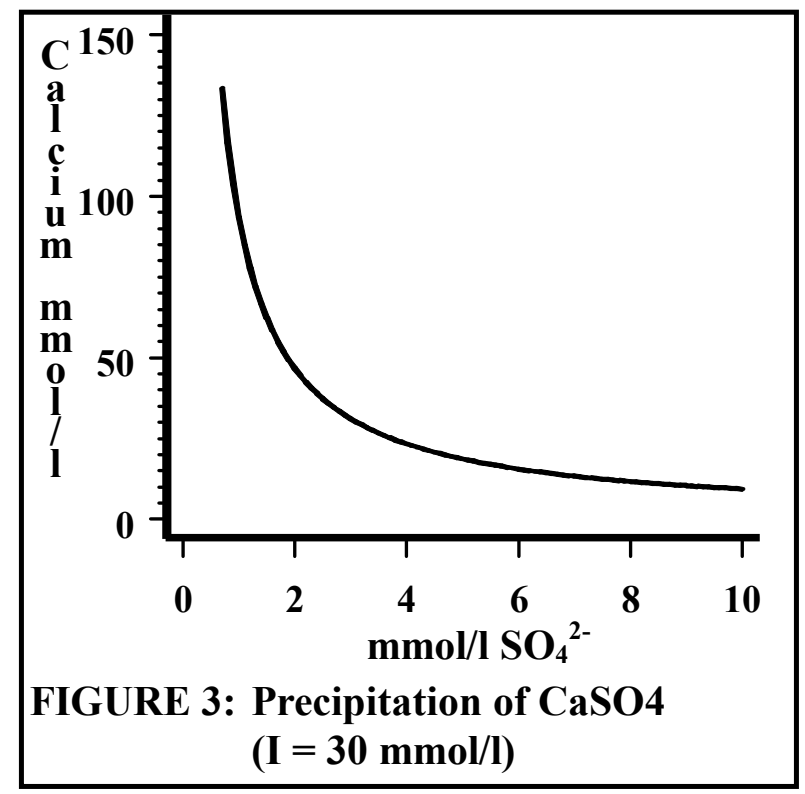




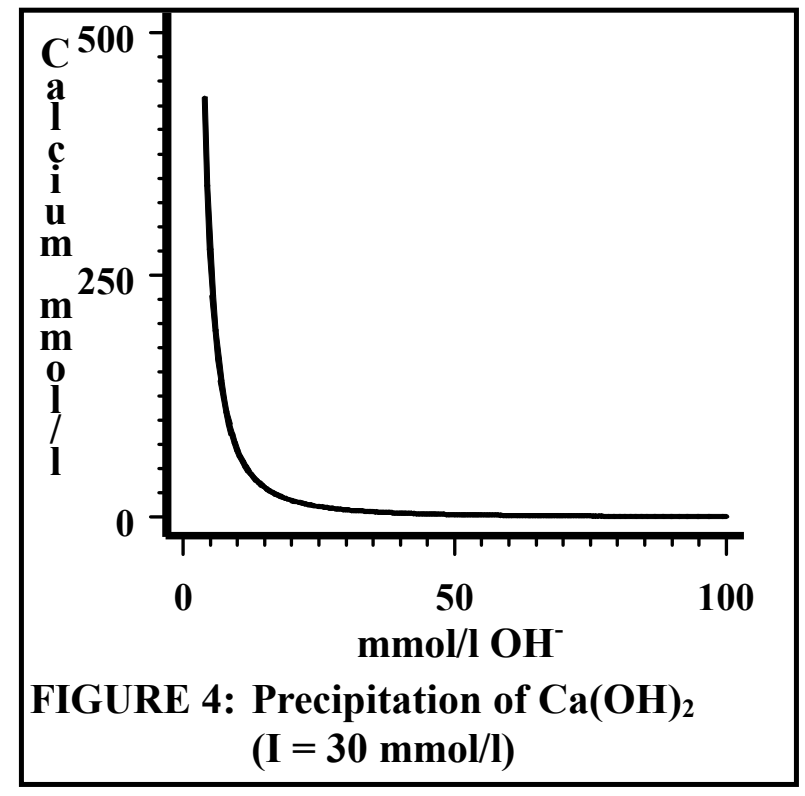




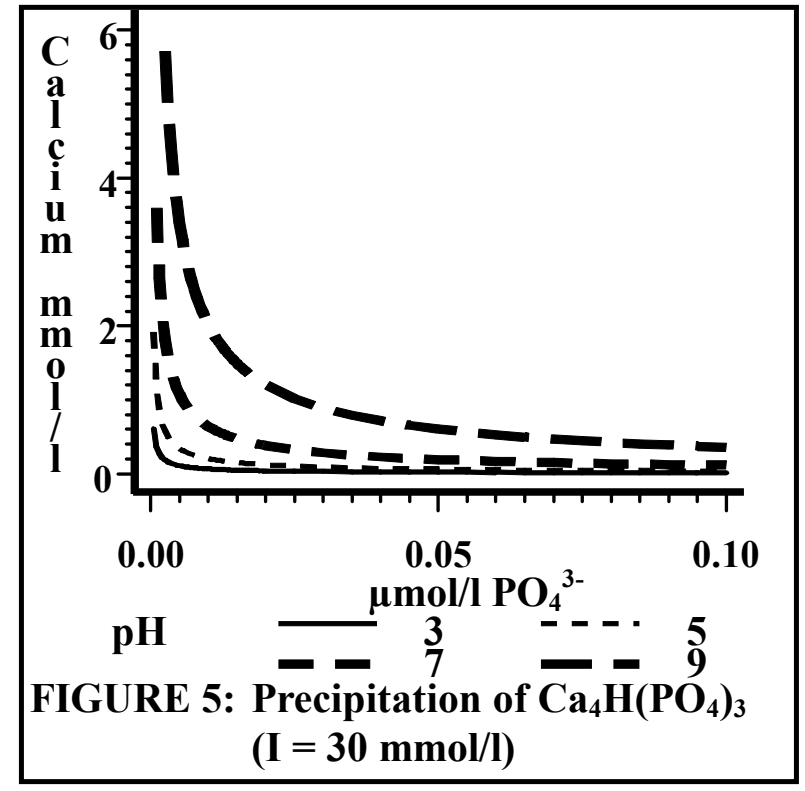




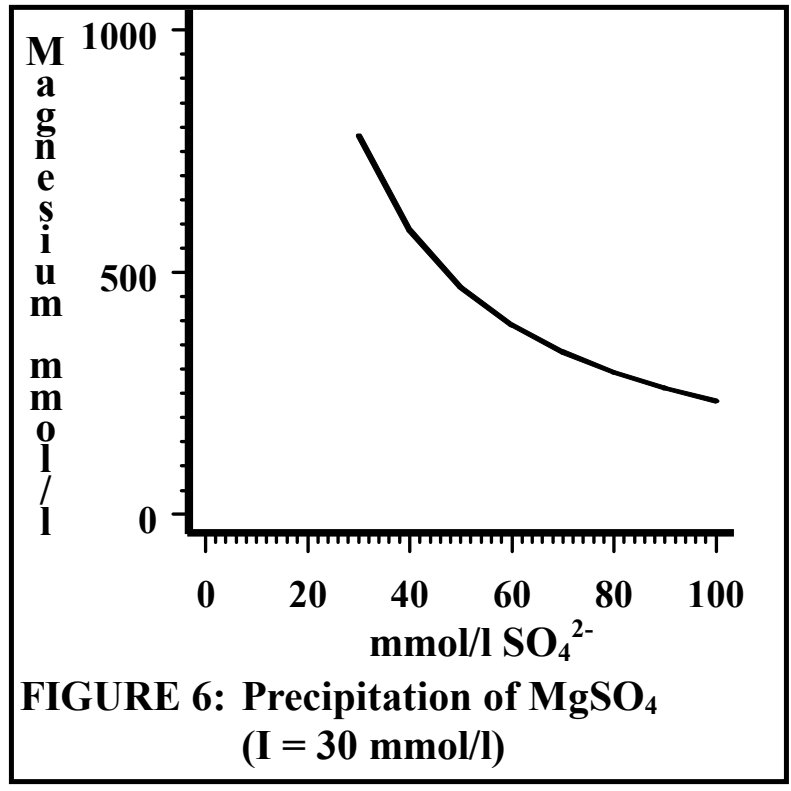




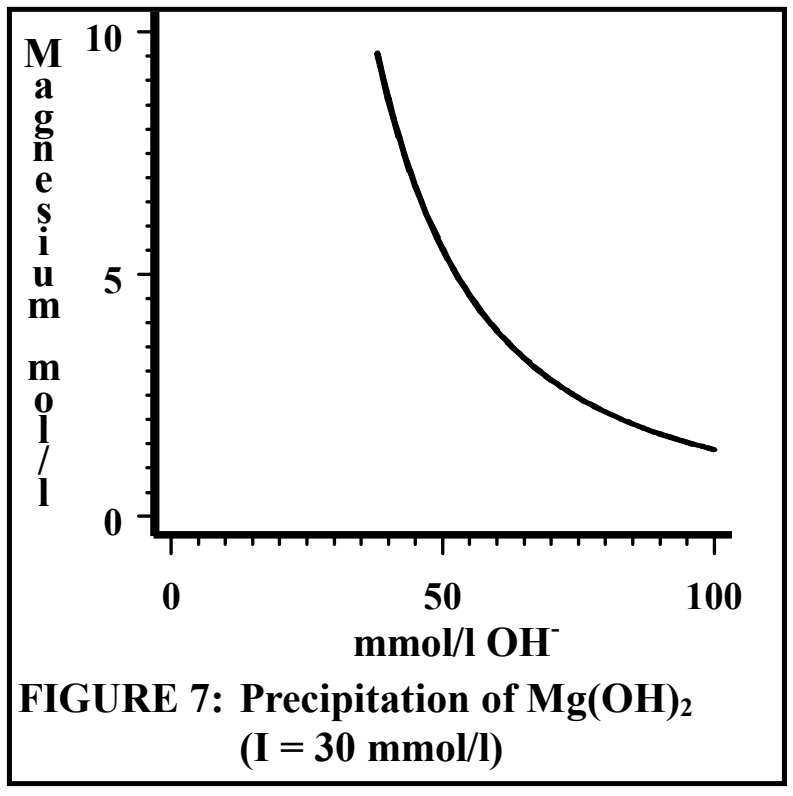




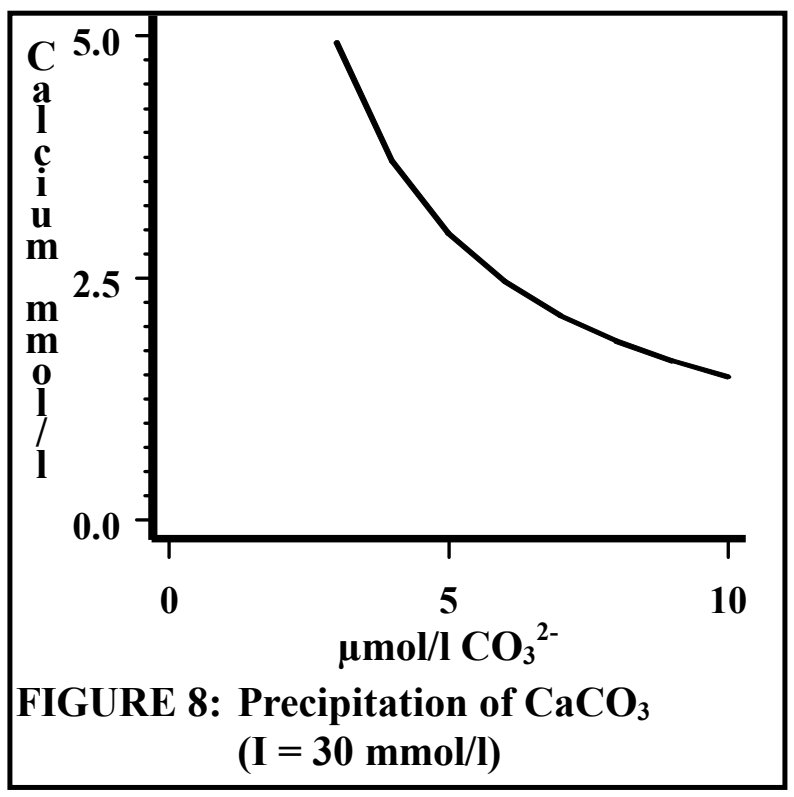




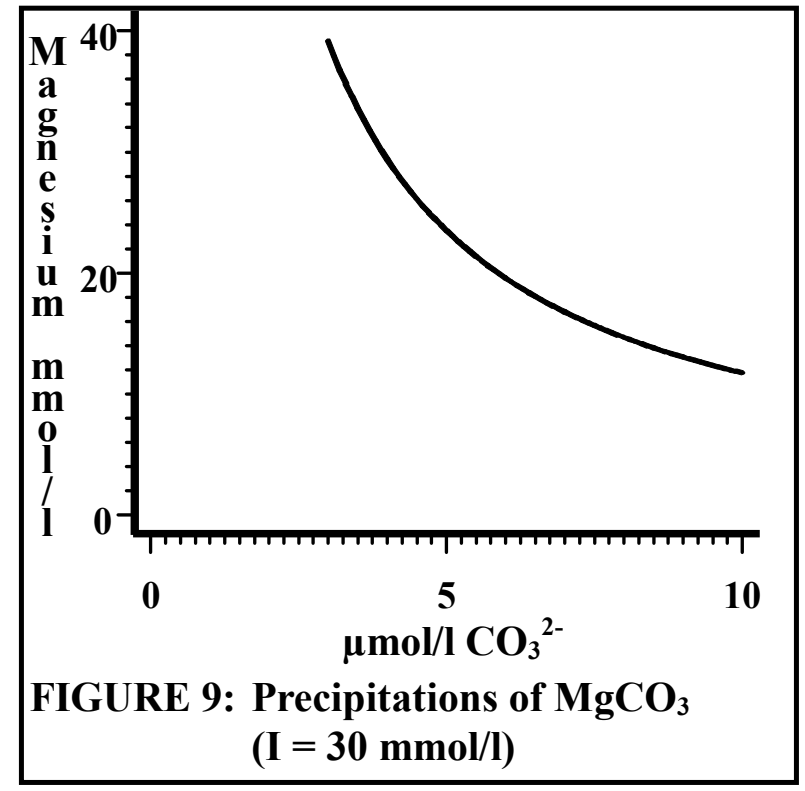




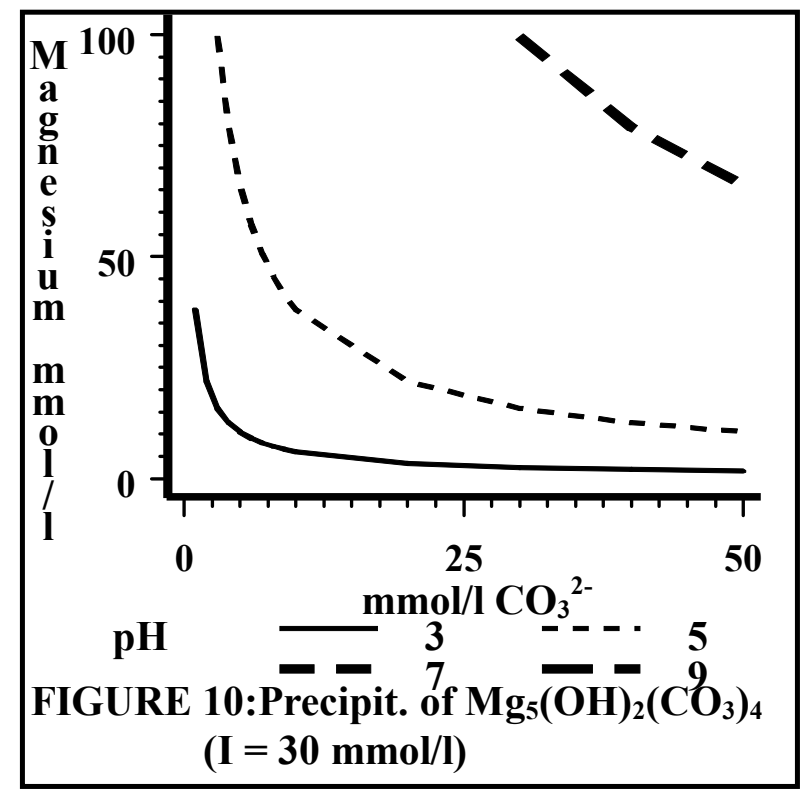

